\title{
Children's Environmental Waste Reduction Education Rawa Simprug IX, South Jakarta, Special Capital Region of Jakarta to Increase Public Awareness of Environmental Issues \\ Wira Aulia ${ }^{1}$, Ari Rahman ${ }^{1}$, Teuku Mahlil ${ }^{2}$, Evi Siti Sofiyah ${ }^{1}$, Ariyanti Sarwono ${ }^{1}$, I Wayan Koko Suryawan ${ }^{1 *}$ \\ ${ }^{1}$ Department of Environmental Engineering, Faculty of Infrastructure Planning, Universitas Pertamina, Jakarta, Indonesia \\ ${ }^{2}$ Department of Civil Engineering, Faculty of Infrastructure Planning, Universitas Pertamina, Jakarta, Indonesia
}

Submitted: March $3^{\text {rd }}$ 2021; Revised: November 16 $6^{\text {th }} 2021$; Accepted: November $26^{\text {th }} 2021$

Keywords:

Environmental

Plastic

Reduction

Student

\begin{abstract}
Education is something that serves as a foundation for humans. As educational activists, we can raise a better generation by conducting teaching activities for the nation's children to hone their academic and non-academic abilities outside formal schools. The large number of students dropping out of school causes non-formal education to have an important role in fostering environmental awareness. This activity aims to foster a sense of concern for environmental knowledge, especially among children in Rawa Simprug IX, South Jakarta, Special Capital Region of (DKI) Jakarta. In addition, it also aims to enhance children's interest in reading from an early age and their understanding of various lessons that have been or have not been obtained in formal schools. This activity was conducted from August 2019 to November 2019. The peak of the event was held on Sunday, November 24, 2019. In this activity, several books could be loaned to children for on-the-spot reading (in the Madani Rubric). The book was carried by a mobile library car from the South Jakarta Administration City Library and Archives Service. There were approximately 30 children of Rawa Simprug IX who took part as the participants in this event. This activities teach children in the Rawa Simprug IX area who need additional education with the help of HMTL (Himpunan Mahasiswa Teknik Lingkungan) and some lecturers from Pertamina University as the teaching staff. The children were also taught about the environment, particularly reducing plastic waste by using drinking bottles. The achievement of this activity is a recycling product made by the target community themselves.
\end{abstract}

\section{INTRODUCTION}

Education is essential to be given as early as possible. Apart from being critical, education can also shape character, broaden horizons, understand ethics, and serve as preparation for a career. Non-formal education for children needs to be implemented gradually to increase the level of formal education. One of them is children's interest in reading. The lack of children's interest in reading is a factor that influences their lack of environmental awareness. This is triggered by humans' less concerned behaviour toward their environment, which causes the condition of the natural environment to detriorate (Ulhasanah \& Goto, 2018). Besides, the quality of the living environment is currently decreasing due to excessive exploitation of nature without regard for the environment's carrying capacity and ecological functions. Children's environmental care behaviour must be instilled continuously through habituation (Adawiah, 2019). Environmental care aspects developed in schools include the habit of maintaining the cleanliness and preservation of the school environment, providing

ISSN 2460-9447 (print), ISSN 2541-5883 (online)

*Corresponding author : I Wayan Koko Suryawan

Department of Environmental Engineering, Faculty of Infrastructure Planning, Universitas Pertamina, J. Teuku Nyak Arief, Simprug, Kebayoran Lama, DKI Jakarta 12220, Indonesia

Email: i.suryawan@universitaspertamina.ac.id 


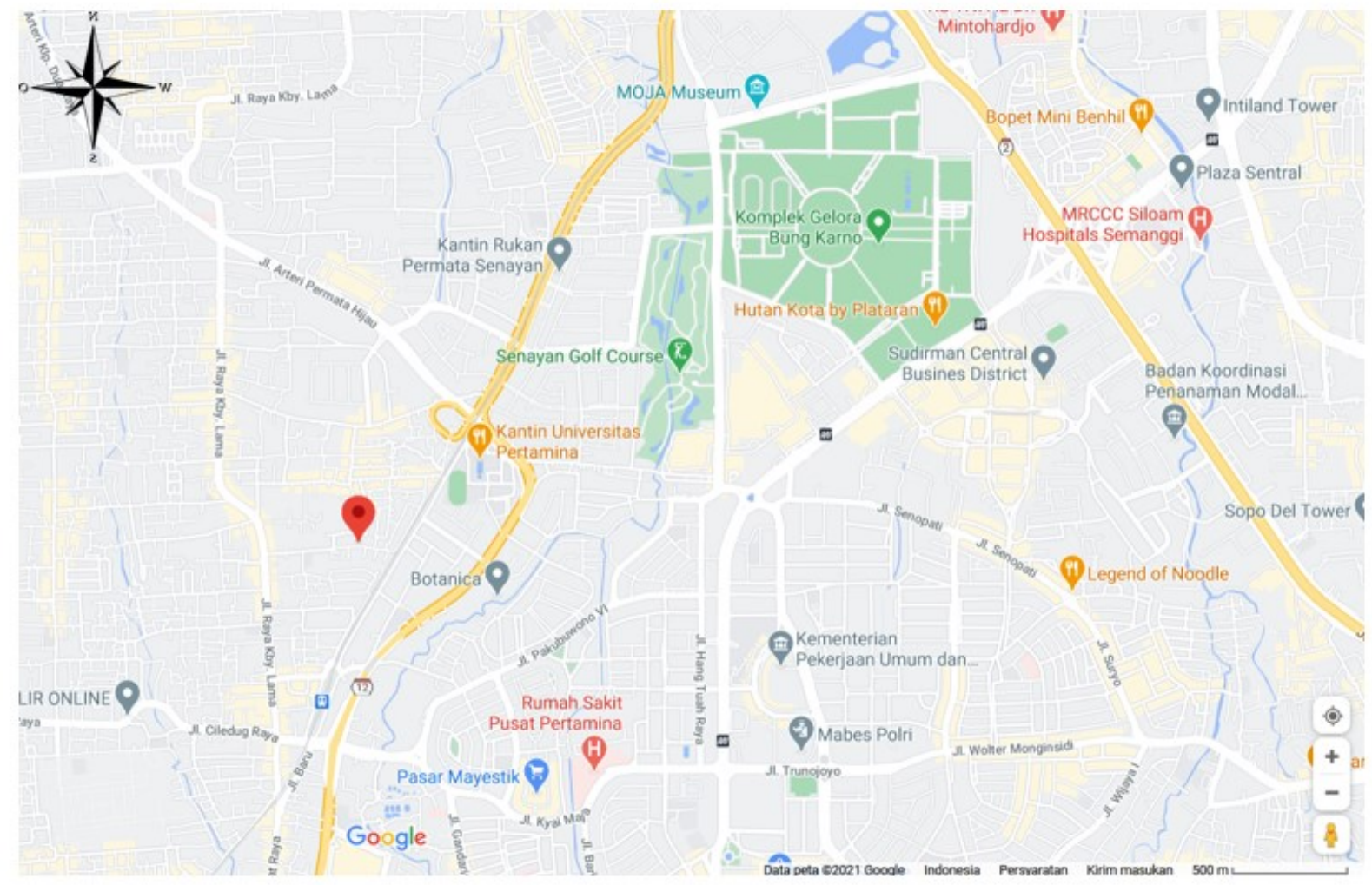

Figure 1. Location of activity implementation

garbage disposal sites, separating organic and inorganic types of waste, providing cleaning equipment, and conducting environmental care programs. One example of people's habits is producing plastic bottle waste (Žukauskiené et al., 2020).

Using tumblers or drinking bottles significantly support the government's campaign in encouraging people to reduce plastic use and switch to refillable beverage containers. This movement will make life healthier and reduce expenses. Children can bring this type of tumblers to school. A tumbler with a capacity of 300-450 milliliters is quite suitable for school children. Children can lessen their environmental impact and gain awareness by using a tumbler as a substitute for a drinking water container. Children who bring their own drinking container when buying food can also save money. Character development involves caring for an important environment that is instilled from an early age. One way to develop this character is through education (Widyaningrum, 2016). An environmentally conscious school will support the emergence of a caring attitude toward the environment. Environmental consciousness may be described as emotional attitudes toward the surroundings that emotionally and conceptually encourage students to admire, fear, and behave extra nicely toward the surroundings (Cui et al., 2015).

The use of plastic food and beverage containers continues to increase. According to data from the Indonesian Plastics Industry Association and the Central Statistics Agency, plastic waste in Indonesia reaches 64 million tons per year (Mahmud, 2020; Nur et al., 2021). Using a tumbler or drinking bottle that can be used repeatedly can be one way to reduce plastic waste from drinking water packaging. Minimizing the use of plastic bags is certainly not easy and requires a consistent and continuous campaign. On February 21, 2016, the Paid Plastic Bag campaign coincided with National Garbage Day to aim Waste-Free Indonesia 2020 (Khoiruman \& Haryanto, 2017). During the campaign's launching, reusable shopping bags were distributed, and a policy regarding plastic bag was imposed. This policy requires customers to pay an additional Rp. 200, if they still want to use plastic bags. For this reason, reusable bags are given to children in this service to reduce plastic waste and save their money.

As educational activists, we can help to raise a better generation by conducting teaching activities for the nation's children to hone their academic and nonacademic abilities outside formal schools. Therefore, sharing knowledge, running books, and environmental education are some community service activities conducted by the Environmental Engineering Study Program of Pertamina University in teaching the nation's children. This community service activity aims to deliver knowledge to children about the environment, specifically reducing plastic bottle waste by carrying a tumbler or drinking bottle anywhere and preserving it. Moreover, it also aims to foster a sense of concern for the surrounding community among the members of the Environmental Engineering Study 
Program of Pertamina University, particularly in education field.

\section{METHOD}

The implementation of this program is not only teaching in the academic field but also non-academics such as art. Moreover, there will be a running book available for children to borrow and read on the spot (at Rubric Madani). The book was carried by a mobile library car from the South Jakarta Administration City Library and Archives Service. Besides, children are also given knowledge about the environment and encouraged to reduce plastic waste by bringing drinking bottles. These drinking bottles were distributed to the children for free, with the hope that by using them, they will reduce their usage of plastic waste. The use of paid plastic bags is felt to be detrimental to children. The provision of reusable bags is handled to minimize environmental impact.

This activity was held at Jalan Rawa Simprug IX, RT 09/RW 09, South Grogol, Kebayoran Lama, South Jakarta City. It was routinely held every month from August 2019 to November 2019. The event's peak date is Sunday, November 24, 2019. Each month, 10-3students participate in this activity.

\section{RESULT AND DISCUSSION}

This activity is in collaboration with Rubric Madani, one of the non-formal educational institutions for children. This activity teaches children in the Rawa Simprug IX area who need additional education, with volunteers from HMTL UP, lecturers UP, and Rubric Madani administrators. Figure 2 depicts the documentation of teaching activities by HMTL UP. It is expected that the community will be more concerned about waste and the surrounding environment as well as reduce the amount of waste to the maximum through this socialization. As a society that will continue the advanced generation, we must know the benefits of waste. Organic waste can be used as recycled material, namely as fertilizer for plants, fruit, and others (Ansari et al., 2020). Meanwhile, inorganic waste can be recycled into crafts and others. Moreover, residue is non-recyclable waste that must be disposed directly into sanitary landfills (Liu et al., 2017). Waste that is not managed properly will cause many problems, such as leachate, greenhouse gases, and an increase in marine debris (Septiariva \& Suryawan, 2021; Suryawan et al., 2021; Yodi et al., 2020).

Teaching activities are conducted by giving lectures every week. The lecture material is delivered interactively. The material includes an insight of an awareness toward the environment and it is provided by a representative of the HMTL UP. The objectives correspond with Kuntoro's statement that that if nonformal education is seen as community education, the forms, goals, and activities of non-formal education should touch all dimensions of community life (Kuntoro, 2006). It is because the concept of lifelong education emphasizes that all life activities can be interpreted as learning activities. Environmental teaching is the procedure of identifying values and clarifying ideas to increase the competencies and attitudes essential to recognize and compare the connection among human beings, their lifestyle, and the biophysical environment (Türkoğlu, 2019). Environmental teaching, which is entirely based on sustainability concepts that concentrate on how humans and nature can coexist in efficient harmony, is a method that permits people to find out environmental issues, take part in fixing those issues, and initiate an act to enhance the environment (Türkoğlu, 2019).

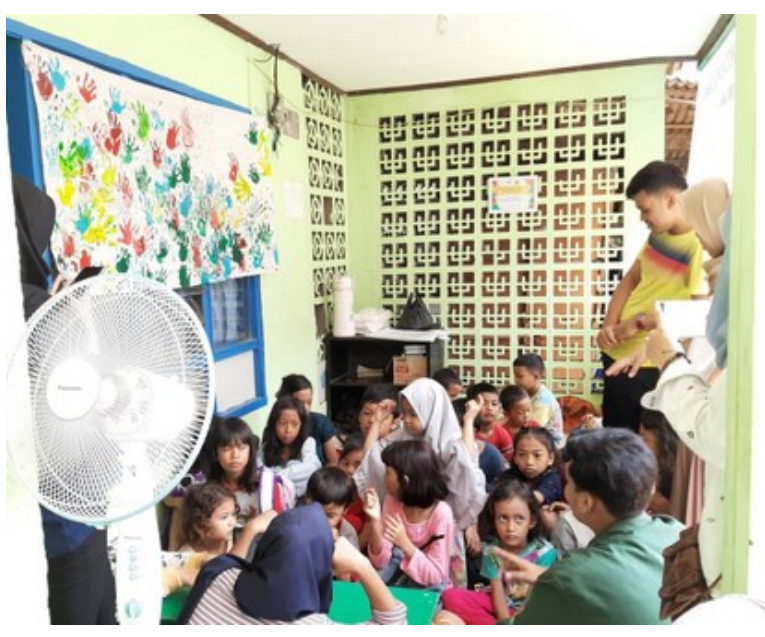

Figure 2. Educational activities conducted by HMTL UP

Children are given knowledge about the environment as well as encouraged to reduce the use of plastic waste. Besides, they are also given the examples of negative impact of poor environmental management due to plastic bags and plastic bottles. It requires solid efforts to change people's behavior into proenvironmental by no longer using plastic bags and replacing them with reusable bags. Even if just through non-formal teaching, this program is expected to provide insight into plastic waste reduction which can increase the community's love toward the environment. According to Baro'ah and Qonita, a school that implements no plastic waste program contributes in providing character education for students to love environment (Baro'ah et al., 2020). In this program, Students are taught to love their environment by getting used to bring their drinking bottles from home, not buying food and drinks wrapped in plastic, and so on. This program can create a clean school environment to support students' and other school members' physical health. Besides, reducing plastic use has many positive impacts.

At the end of the activity, education on waste recycling was delivered. The Recycled Principle was implemented since items that are no longer useful can 
be recycled (Arisona, 2018). Although not all goods can be recycled, there are many informal and home industries that will use the waste for other goods. It was done the committee and participants took a picture together (Figure 3).

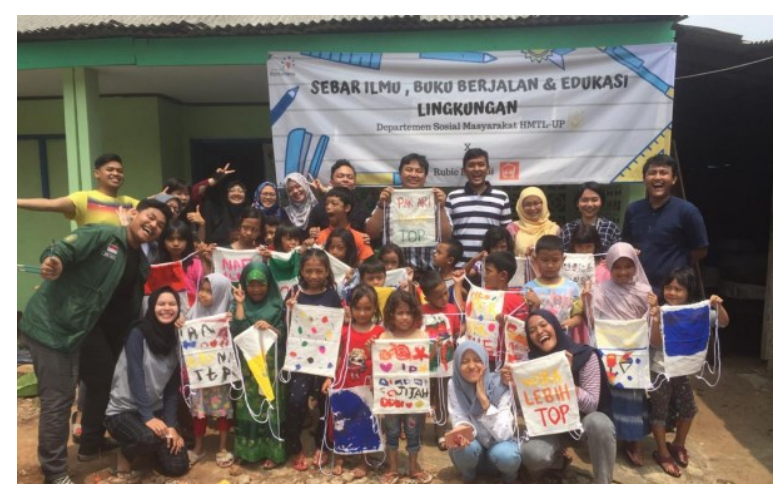

Figure 3. Documentation of community service activities

\section{CONCLUSION}

Besides socialization, there is also waste recycling training, which at the very least can expand the environmental knowledge of children around Rawa Simprug IX, South Jakarta, DKI Jakarta. Environmental knowledge programs that encourage students to love the environment and develop healthy habits can be taught to children so they will apply it in their daily lives as early as possible. School environmental activities, especially those related to plastic waste reduction, are implemented when students are in the school. These activities are expected to develop habits that positively impact students when they are at home and in the community.

\section{ACKNOWLEDGMENT}

We would like to send our gratitude to Rubric Madani for the cooperation and opportunity to provide counseling service. This community service is one of Pertamina University's annual Students' Creativity Program (PKM) grants in 2019 (Decree No. 0043/UP$\mathrm{R} / \mathrm{SK} / \mathrm{II} / 2020$.

\section{REFERENCES}

Adawiah, R. (2019). Instilling the Environmental Care Characters to the Elementary Schools Located on the River Banks. Journal of Wetlands Environmental Management, 6(2), 84. https://doi.org/10.20527/jwem.v6i2.177

Ansari, A. A., Ori, L., \& Ramnarain, Y. I. (2020). An Effective Organic Waste Recycling Through Vermicompost Technology for Soil Health Restoration BT - Soil Health Restoration and Management (R. S. Meena (ed.); pp. 83-112). Springer Singapore. https://doi.org/10.1007/978981-13-8570-4_3

Arisona, R. D. (2018). Pengelolaan Sampah 3R (Reduce, Reuse, Recycle) Pada Pembelajaran Ips Untuk Menumbuhkan Karakter Peduli
Lingkungan. Al Ulya: Jurnal Pendidikan Islam, 3, 39-51.

Baro'ah, S., Siti, D., \& Qonita, M. (2020). Penanaman CiLi (Cinta Lingkungan) Pada Siswa Melalui Program Lingkungan Sekolah Tanpa Sampah Plastik. Jurnal PANCAR (Pendidik Anak Cerdas Dan Pintar), 4(1), 11-16. https://ejournal.unugha.ac.id/index.php/pancar/a rticle/download/309/252

Cui, J., Jo, H., \& Velasquez, M. G. (2015). The Influence of Christian Religiosity on Managerial Decisions Concerning the Environment. Journal of Business Ethics, 132(1), 203-231. https://doi.org/10.1007/s10551-014-2306-5

Google Map. (2021). Google Map. https:/www.google.com/maps/place/

Khoiruman, M., \& Haryanto, A. T. (2017). Green Purchasing Behavior Analysis of Government Policy About Paid Plastic Bags. Indonesian Journal of Sustainability Accounting and Management, $\quad 1(1), \quad 31$. https://doi.org/10.28992/ijsam.v1i1.25

Kuntoro, S. A. (2006). Pendidikan Nonformal (Pnf) Bagi Pengembangan Sosial. Jurnal Ilmiah VISI PTK-PNF, 1(2), 14-18. https://core.ac.uk/download/pdf/295555318.pdf

Liu, Y., Xing, P., \& Liu, J. (2017). Environmental performance evaluation of different municipal solid waste management scenarios in China. Resources, Conservation and Recycling, 125, 98-106.

https://doi.org/https://doi.org/10.1016/j.resconre c. 2017.06 .005

Mahmud, M. (2020). Learning and Education of Environmental Hadith in a Bloom Taxonomy Perspective: An Effort to Raise the Ecological Quotient. Ushuluddin International Conference (USICON). http://ejournal.uinsuka.ac.id/conference/index.php/USICON/articl e/view/315

Nur, A., Saragih, F., Mega, R., Wardah, N., \& Luthfiah, Z. (2021). Upaya Dalam Mengurangi Limbah Sampah Plastik Melalui Aplikasi Amara Recycle. 01(01), 1-6.

Septiariva, I. V. A. Y., \& Suryawan, I. W. K. (2021). Development of water quality index (WQI) and hydrogen sulfide $(\mathrm{H} 2 \mathrm{~S})$ for assessment around suwung landfill, Bali Island. Journal of Sustainability Science and Management, 16(4), 137-148.

Suryawan, I. W. K., Sarwono, A., Septiariva, I. Y., \& Lee, C.-H. (2021). Evaluating Marine Debris Trends and the Potential of Incineration in the Context of the COVID-19 Pandemic in Southern Bali, Indonesia. Jurnal Ilmiah Perikanan Dan Kelautan, 13(1).

Türkoğlu, B. (2019). Opinions of pre-school teachers and pre-service teachers on values education in the pre-school period: The case of Konya province. Pegem Egitim ve Ogretim Dergisi, 
$9(2)$, $381-412$.

https://doi.org/10.14527/PEGEGOG.2019.012

Ulhasanah, N., \& Goto, N. (2018). Assessment of citizens' environmental behavior toward municipal solid waste management for a better and appropriate system in Indonesia: a case study of Padang City. Journal of Material Cycles and Waste Management, 20(2), 1257-1272. https://doi.org/10.1007/s10163-017-0691-4

Widyaningrum, R. (2016). Pembentukankarakter Peduli Lingkungan Siswa Sekolah Dasar Melalui Sekolah Peduli Dan Berbudaya Lingkungan. Widya Wacana: Jurnal Ilmiah, 11(1), 108-115.

Yodi, Y., Suryawan, I. W. K., \& Afifah, A. S. (2020). Estimation of Green House Gas (GHG) emission at Telaga Punggur landfill using triangular, LandGEM, and IPCC methods. Journal of Physics: Conference Series, 1456(1). https://doi.org/10.1088/17426596/1456/1/012001

Žukauskienè, R., Truskauskaitė-Kunevičienė, I., Gabė, V., \& Kaniušonytė, G. (2020). "My Words Matter": The Role of Adolescents in Changing Pro-environmental Habits in the Family. Environment and Behavior, 53(10), 1140-1162. https://doi.org/10.1177/0013916520953150 